Winter 2013

\title{
What Could Be Gained in Translation: Legal Language and Lawyer-Linguists in a Globalized World
}

\section{Samantha Hargitt}

Indiana University Maurer School of Law, shargitt@gmail.com

Follow this and additional works at: https://www.repository.law.indiana.edu/ijgls

Part of the International Law Commons, and the Linguistics Commons

\section{Recommended Citation}

Hargitt, Samantha (2013) "What Could Be Gained in Translation: Legal Language and Lawyer-Linguists in a Globalized World," Indiana Journal of Global Legal Studies: Vol. 20 : Iss. 1 , Article 14.

Available at: https://www.repository.law.indiana.edu/ijgls/vol20/iss1/14

This Note is brought to you for free and open access by the Law School Journals at Digital Repository @ Maurer Law. It has been accepted for inclusion in Indiana Journal of Global Legal Studies by an authorized editor of Digital Repository@Maurer Law. For more information, please contactrvaughan@indiana.edu.

\section{$\Psi$}

JEROME HALL LAW LIBRARY

INDIANA UNIVERSITY

Maurer School of Law
Bloomington 


\title{
What Could Be Gained in Translation: Legal Language and Lawyer-Linguists in a Globalized World
}

\author{
SAMANTHA HARGITT*
}

\begin{abstract}
Translation and interpretation have long played a vital role in many legal contexts, from providing equal rights to defendants to facilitating mutual understanding among the members of the United Nations. Legal language, though, is incredibly complex and even faithfully equivalent translations can fail to meet the high standards required for operation in international legal contexts, where a lack of understanding over a single term could mean the difference between a material and non-material breach in a treaty or transnational contract. Branches of linguistics, such as comparative legal linguistics and forensic linguistics, study the characteristics and functions of legal language across many tongues. As the globalization of our world continues, the opportunities for confusing and misunderstanding legal language increase. While a global legal language could, by some views, be the ultimate fix to such issues, the current state of international systems is poorly equipped to develop such a structure. The timing is simply not right at this point in the process of globalization. This note examines the current context and state of legal translation and similar areas of linguistic study and takes the view that, instead, the role of the lawyer-linguist professional and the technique of co-drafting should be maximized to facilitate better understanding among languages and legal systems.
\end{abstract}

* Articles Editor, Indiana Journal of Global Legal Studies; J.D. Candidate, 2013, Indiana University Maurer School of Law; B.A., Spanish and Linguistics, 2009, University of North Carolina Chapel Hill. I would like to point out that while this note draws on research in the fields of linguistics and translation, it is directed at a legal audience and does not always distinguish the separate areas of study as they are so closely bound together for the purposes of this topic. I would like to thank everyone who helped and supported me in the writing of this note at every stage. In particular, I would like to thank my family for their constant love and encouragement.

Indiana Journal of Global Legal Studies Vol. 20, Issue 1 (2013)

(C) Indiana University Maurer School of Law 


\section{INTRODUCTION}

Imagine yourself as the mayor of a small colonial town in the Americas in the early 1600 s. Your settlement is experiencing problems with the native population-you hammered out details of an agreement to purchase their land for settlement months ago, but they just do not seem to understand the concept of trespass now that you and your settlors own the land. ${ }^{1}$ You have decided to negotiate further to find a solution to this property ownership problem. There is one major issue, however: You don't speak their language, and they don't speak yours. The interpreter you used for the land sale has long since left the area, but a bright young man in town has been learning the native tongue for some time now. At the negotiations, no problems appear. Everyone agrees on land use and seems to understand the implications of land ownership. Even still, the same problems continue to resurface only a short time after the supposed successful negotiation. What do they not understand?

The problem in this scenario is not that the interpreters used the wrong words, but that the concepts involved were so linked to the cultural and legal systems from which they arose that it was impossible to achieve mutual understanding of the words without the same level of understanding of the underlying systems. While such a circumstance was common during colonization and created numerous disputes, ${ }^{2}$ conceptually similar interactions continue to take place today. Furthermore, the importance of such interactions is magnified in our globalized world, where interactions between different languages and cultures happen regularly and the speed of transactions gives quick mutual comprehension even higher value.

"Language" is a much broader term than is typically thought and includes not only the standard conception of languages (French, Spanish, English), but also "languages" such as dialects and professional jargon. Legal language, or legalese, is one such jargon used by lawyers, government officials, and others in fields related to the legal profession for court documents, legislation, and more. ${ }^{3}$ Though there has long been a clear link between language and the law, increasingly,

1. David Walbert, Who Owns the Land?, North Carolina: A Digital History, http://www.learnnc.org/lp/editions/nchist-colonial/2027 (last visited Sept. 29, 2012) (discussing the differing concepts of property for colonial settlors and existing native populations).

2. See id.

3. HeikKI E. S. MATTILA, CompaRative Legal Linguistics 3-4 (Christopher Goddard trans., 2006). 
linguists ${ }^{4}$ are studying the "technolect," or technical dialect, of legal language in the comparative and forensic contexts as an interdisciplinary study, collectively termed "legal linguistics." Comparative linguistics, which is based largely on a geographic viewpoint, has come to play a particularly large role in the globalizing world as the need for competent translators and interpreters in every language continues to increase.

Legal language did not develop recently, but has a rich history going back thousands of years. ${ }^{8}$ While based on ordinary language, legal language is a jargon primarily characterized by a complex and specialized lexicon, which requires interpretation to be understood and often makes the language completely foreign and incomprehensible to a layperson. ${ }^{9}$ The Latin genesis of many of the terms makes it even less accessible, ${ }^{10}$ and frequent polysemy ${ }^{11}$ adds to the confusion. Despite the ancient roots of legal language and the relationship between language and the law, legal linguistics has developed rather recently as an area of study. ${ }^{12}$ Furthermore, because of the frequently comparative nature of the science and the use of multiple languages, legal linguistics is often "closely bound up with the science of translation," and by necessary extension, interpretation. Legal linguistics is essentially a theory of the law that "focuses on two central issues of the creation of law with linguistic means and its application, i.e. interpretation and

4. The term linguist refers to those who engage in the scientific study of language and its structure. Definition of Linguist, OXFORDDICTIONARIES.COM, http://oxforddictionaries.com/definition/english/linguist?q=linguist (last visited Sept. 12, 2012).

5. MATTILA, supra note 3 , at 3-4.

6. MARCUS GALDIA, LEGal LinguistiCs 63.65 (2009); MATTILA, supra note 3 , at 8. While "legal linguistics" is a term for this type of study used more commonly outside the United States (where forensic linguistics and the science of translation are treated separately), I will use it here because it is a broader term encompassing both translation and traditional linguistic study and $I$ feel it is more accessible to a legal audience.

7. SAÚl SibIRSKY \& MARTIN C. TAYLOR, LANGUAGE INTO LANGUAGE 13-20 (2010) (discussing recent legislation concerning translation and interpretation and the growing awareness of "limited English proficiency" issues).

8. MATTILA, supra note 3 , at 7 ; see also SIBIRSKY \& TAYLOR, supra note 7 , at 9 (discussing the historical importance of translation and interpretation in many fields).

9. See MATTILA, supra note 3 , at 4 (describing legal language as old, as for special purposes, and as permeating ordinary language).

10. See $i d$. at $52-53$ (discussing how the use of Latin allows lawyers to feel part of a select group).

11. GALDIA, supra note 6, at 99, 100-1; MATTILA, supra note 3, at 109-11.

12. GALDIA, supra note 6 , at 65 ("Legal Linguistics is a relatively new discipline."); MATTILA, supra note 3 , at 8 ("[M]odern linguistics only developed at the beginning of the 20th century.").

13. MatTILA, supra note 3 , at 9 . 
argumentation."14

The most basic function of language is communication. Legal language can communicate everything from the nature of laws to the reasoning underlying decisions. ${ }^{15}$ It also functions as one of the mechanisms that closes the profession to outsiders, creating a group cohesion and camaraderie among lawyers. ${ }^{16}$ The most notable characteristics of this "language" are precision, density, neutrality, formality, and common use of archaisms, including Latin and other foreign words and phrases. ${ }^{17}$ A nonlawyer will rarely read a contract or statute in English and understand the meaning and consequences of every provision, particularly those that cross-reference multiple other provisions or that contain a myriad of defined terms. Consider, for example, the density and unapproachability of the United States Internal Revenue Code. ${ }^{18}$ These functions and characteristics hold true for legal language in every tongue, ${ }^{19}$ and it is the translation of legal jargon between languages that results in arguably the most interesting problems in the realm of legal linguistics and translation.

The history of legal translation and interpretation goes back nearly as far as the history of legal language itself. ${ }^{20}$ Throughout history, "language [has followed] the flag,"21 particularly in the aftermath of wars and similar conquests; as such, native languages have been displaced and translators and interpreters have had a large role in "conditioning both victors and losers to a mutual understanding of the new rules of the road, where the winners write and rewrite history,"22 including legal standards. Recall, for example, the scenario set out at the beginning of this note-history tells us that the colonists ignored native legal concepts and language in favor of their own, European ideas. As in the international law setting, the victor holds the upper hand and may wield its power to impose whatever laws and language it prefers. Because of this pivotal role and the high risk of mistakes and misunderstandings, particularly when unfamiliar cultures are concerned, translators and interpreters have often become the

14. GALDLA, supra note 6 , at 78 .

15. See MATTILA, supra note 3 , at 33 .

16. Id. at 52 (noting especially the role of legal Latin in group cohesion and solidarity).

17. Id. at 65-103 (dedicating a chapter to addressing the characteristics of legal language).

18. I.R.C. $\S \S 1-9834$ (2012).

19. See, e.g., MATTILA, supra note 3, at 68-72 (specifically addressing characteristics of legal definitions in multiple languages).

20. See SIBIRSKY \& TAYLOR, supra note 7, at 95 (noting the differences between translation of text and interpretation of spoken language).

21. Id. at 9 .

22. Id. 
scapegoats of history ${ }^{23}$ blamed for problems on both sides even if their duties were faithfully performed.

Recently, many countries, including the United States, have taken steps to level linguistic playing fields by insuring equal treatment regardless of one's primary language and by enforcing quality and ethical standards among professionals through legislation like the Federal Court Interpreters Act. ${ }^{24}$ The American Bar Association (ABA) adopted the ABA Standards for Language Access in Courts in February of 2012 to aid in the design and implementation of systems to better identify and assist limited English proficient individuals in, or seeking access to, the judicial system. ${ }^{25}$ Even with these standards and experienced translators and interpreters, significant risks remain, including interpreter-originated distortions and simple language mistakes. ${ }^{26}$ Human rights issues can arise rather frequently if texts are not faithfully translated or words not equivalently interpreted. ${ }^{27}$ In spite of the associated risks, translation and interpretation remain the best ways to facilitate mutual discourse and understanding across languages and cultures. As such, every area of the law, from government agencies and courts to private sector corporations engaged in international business transactions, employs translators and interpreters. ${ }^{28}$

One may easily view the study of legal linguistics from two different perspectives: the linguist or translator, ${ }^{29}$ who is often more quantitative,

23. Id. at 130-31 (discussing the historical role of interpreters as scapegoats using the current day stories of "terps," who interpreted for locals and invading forces in Iraq, to illustrate).

24. Court Interpreters Act, 28 U.S.C. $\$ 1827$ (2012); see SIBIRSKY \& TAYLOR, supra note 7, at 13, 27-30 (discussing "legal standards to guarantee full disclosure and due process for all witnesses and defendants in judicial proceedings whose primary language was not English" and the import of ethical standards for interpreters); see also MATTILA, supra note 3, at 17-18 (using the Finnish constitutional provision supporting bilingual citizen's right to use a citizen's own language of either Finnish or Swedish in courts of law as an example).

25. ABA STANDARDS FOR LANGUAGE ACCESS IN COURTS (2012), available at www.abanow.org/wordpress/wp-

content/files_flutter/1326398698_31_1_1_9_resolution_summary.pdf.

26. See SIBIRSKY \& TAYLOR, supra note 7, at 22, 113-14 (discussing how the multidimensional nature of language makes it important to distinguish denotative and connotative differences in words and in literal and figurative translations).

27. See, e.g., id. at 35-36 (discussing the mass round up, arrest, and trial of nonEnglish-speaking immigrant workers employed by a meatpacking plant in Postville, Iowa).

28. Id. at 74-91 (providing an overview of job opportunities for translators and interpreters).

29. Linguist is a term sometimes used to mean translator. Army linguists, for example, are actually translators and interpreters. U.S. Army, About Army Linguists, GOARMY.COM, http://www.goarmy.com/linguist/about.html (last visited Aug. 12, 2012). To 
objective, and distant; ${ }^{30}$ and the lawyer, who connects the language to the history of the law and who is more concerned with comprehension of legal language than with the syntactical structure or frequency of particular words. ${ }^{31}$ The main focus of legal linguistics, at least in the comparative form, has become understanding legalese in and across languages. $^{32}$ Comprehensive understanding is difficult enough to achieve from the hermetic language in a single tongue, but cross-lingual understanding can only be achieved through understanding the cultures and legal systems in which the respective languages are based. ${ }^{33}$

\section{The Role of Legal Language in Globalization}

The view of the study of legal linguistics taken here relates very closely to the process of globalization. ${ }^{34}$ Globalization refers to the process of moving from local to international and global scales, including governance and the transnational circulation of ideas, goods, and languages. ${ }^{35}$ It is the erasure of certain borders and an increase in the fluidity of ideas across cultures and countries. Globalization in action takes many forms, including increased transnational trade, international cooperation and dissemination of knowledge, foreign direct investment, and migration of populations. ${ }^{36}$ Some envision continued globalization as the path toward a harmonious global

avoid redundancy, the term linguist is used here to mean one who studies traditional linguistics, where possible, and translator means one who performs translation and interpretation services.

30. See MATTILA, supra note 3 , at 10.

31. Id.

32. Id. at 11 .

33. See Snježana Husinec, The Use of Comparative Legal Analysis in Teaching the Language of the Law, in 117 LEGAL DISCOURSE ACROSS LANGUAGES AND CULTURES 155, 155 (Maurizio Gotti \& Christopher Williams eds., 2010) (discussing the importance of the connectivity between legal language and societal culture).

34. Globalization is the "closer integration of the countries and peoples of the world ... brought about by the enormous reduction of costs of transportation and communication, and the breaking down of artificial barriers to the flows of goods, services, capital, knowledge, and (to a lesser extent) people across borders." JosEPH E. STIGLITZ, GLOBALIZATION AND ITS DISCONTENTS 9 (2002).

35. There are as many definitions of globalization as there are academics studying it. This particular definition is my own resulting from my own reading, study, and experiences. For a comprehensive review of the many definitions of globalization, see generally Nayef R.F. Al-Rodhan and Gérard Stoudmann, Definitions of Globalization: $A$ Comprehensive Overview and a Proposed Definition, Geneva CENTRE For SECURITY PoLJCY, June 19, 2006, available at http://www.gcsp.ch/Emerging-SecurityChallenges/Globalisation/Publications/Articles/Definitions-of-Globalization-A-

Comprehensive-Overview-and-a-Proposed-Definition.

36. See STIGLITZ, supra note 34 , at 9-10. 
community, but this viewpoint is not without critics who suggest that achieving global goals requires that only a "minimum level of 'community' [is] necessary.,"37

In the context of legal linguistics, globalization refers to the movement of legal systems and languages worldwide from the localized to the global. ${ }^{38}$ Legal language, however, remains largely localized because of its inherent link to the culture that bore it. It is both culturally and linguistically relative. Even with such an inherent link to local culture, many states find it necessary to declare a "lingua franca," 39 particularly in bilingual or multilingual countries, ${ }^{40}$ and sometimes a major legal language is simply employed as a lingua franca in other contexts, like in India where English is a working language because of the multiplicity of national languages. ${ }^{41}$ Language rivalries also present a barrier in linguistic globalization as some languages (particularly Indo-European ${ }^{42}$ languages) often hold greater sway due to the size of the speaking population, and also due to the relative economic and political power of Indo-European speaking states in general. ${ }^{43}$ The fact that these rivalries exist, however, attests to the occurrence of linguistic globalization. Within the realm of private law, the inclusion of choice-of-language and choice-of-law clauses in contracts

37. See, e.g., Frank J. Garcia, Globalization, Global Community and the Possibility of Global Justice, in BOSTON COLLEGE LAW SCHOOL FACULTY PAPERS 1, 2 (2005), available at http://lawdigitalcommons.bc.edu/lsfp/33.

38. See SuSAN ŠARČEvić, NEW APPROACH TO LEGAL TRANSLATION 1 (1997) (using the example of international trade in the European Market for its local translations moving local legal systems to the global scale).

39. "[A] language that is adopted as a common language between speakers whose native languages are different." Definition of Lingua Franca, OXFORDDICTIONARIES.COM, http://oxforddictionaries.com/definition/english/lingua\%2Bfranca (last visited Sept. 12, 2012).

40. See MatTiLA, supra note 3, at 17 ("Legal linguistics is closely connected with language law. . . . According to Gérard Cornu . . . language law covers, on the one hand, legal effects of and, on the other hand, legal rules on the use of language."); see also Court Interpreters Act, 28 U.S.C. $§ 1827$ (1996) (having everything translated into English).

41. See R.L.G., English in India: When does it stop being $a$ foreign language? JoHNSON LANGUAGE BLOG (Feb. 18, 2011, 2:58), http://www.economist.com/blogs/johnson/2011/02/english_india. See MATTILA, supra note 3 , at 23 .

42. "[R]elating to the family of languages spoken over the greater part of Europe and Asia as far as northern India." Definition of Indo-European, OXFORDDICTIONARIES.COM, http://oxforddictionaries.com/definition/english/Indo-European (last visited Sept. 12, 2012) (comprising twelve branches of language: Indic (including Sanskrit), Iranian, Anatolian (including Hittite), Armenian, Hellenic (Greek), Albanian (or Illyrian), Italic (including Latin and the Romance languages), Celtic, Tocharian, Germanic (including English, German, Dutch, and the Scandinavian languages), Baltic, and Slavic (including Russian, Polish, Czech, Bulgarian, Serbian, and Croatian)).

43. MATTILA, supra note 3 , at 23. 
for all sorts of international business transactions, from simple sales of goods to complex concession agreements, is another example of language dominance through the power of negotiation. ${ }^{44}$ As barriers erode and boundaries blur, the desire for states to assert their dominance, in whatever form, increases.

\section{A. The Example of the European Union}

Because of the tension between globalizing interactions and the desire to either gain or maintain linguistic dominance, translators and interpreters remain imperative professionals in the legal realm. ${ }^{45}$ Understanding legal discourse and culture in multiple tongues is the key to better understanding legal language as a whole in a globalized context. The European Union (EU) provides an excellent example of the concept of globalization and the associated concerns for multilingual states or organizations on a somewhat smaller, continental scale.

There are twenty-three official languages in the European Union, which are the national tongues of each member state. ${ }^{46}$ Such a pluralistic policy often gives rise to the same problems that plague most transactions involving multiple legal languages: "[T]erminological inconsistency and incoherence in EU directives . . sometimes pose a threat to cross-border transactions." ${ }^{\text {47 }}$ Judges are sometimes called upon to interpret versions of $\mathrm{EU}$ regulations and directives in multiple languages and to issue an opinion that does not create unnecessary conflict among the various authentic versions of legislation. ${ }^{48}$ In the

44. See, e.g., Peter Winship, Changing Contract Practices in the Light of the United Nations Sales Convention: A Guide for Practitioners, 29 INT'L LAW. 525, 540-41 (1995) (discussing examples of choice of language and choice of law clauses).

45. See generally ŠARČEIĆ, supra note 38 (concentrating on translations that become authoritative sources of law, especially in Canada, Switzerland, Belgium, and the European Union).

46. See Eur. Comm'n, Official EU Languages, EUR. CoMM'N, http://ec.europa.eu /languages/languages-of-europe/eu-languages_en.htm (last updated July 23, 2012) (listing Bulgarian, Czech, Danish, Dutch, English, Estonian, Finnish, French, German, Greek, Hungarian, Irish, Italian, Latvian, Lithuanian, Maltese, Polish, Portuguese, Romanian, Slovak, Slovene, Spanish, and Swedish as the official languages of the European Union).

47. Maurizio Gotti \& Christopher Williams, Introduction, in 117 LEGAL Discourse aCross Languages and Cultures 7, 9 (Maurizio Gotti \& Christopher Williams eds., 2010).

48. See, e.g., Summary Report of the European Commission Legal Services on How to Interpret Legislation Which is Equally Authentic in Twenty Languages (Oct. 20, 2003), available at http://ec.europa.eu/dgs/legal_service/seminars/agjacobs_summary.pdf; see also Case 283/81, Srl CILFIT v. Ministry of Health, 1982 E.C.R. 3417, 3430 (1982) (holding that a national court may not decide a particular matter regarding interpretation of EU law is clear unless every language's version has been examined). 
particular setting of the European Union, the problem of incoherence has ignited "a lively debate ... on the crucial role of language in the harmonization process and the need for a Pan-european legal language as a precondition for greater convergence in areas of private law."49

\section{B. Problems with a Proposed Pan-European Language}

In an effort to harmonize certain areas of private European law, especially contract law, the European Commission (EC) began a longterm project known as the Common Frame of Reference (CFR). ${ }^{50}$ It was intended to resolve many of the issues of "consistency and adequacy of [certain] EC legislation." "This has led to debate on both the legal and linguistic fronts suggesting both the possibility of a pan-European language by some, ${ }^{52}$ and even "[optimism] that it will eventually lead to the creation of a new ius commune europaeum." 53 Susan Sarčević, author of Creating a Pan-European Legal Language, which examines the CFR and its goals, ${ }^{54}$ points out, however, that such radical advances are questionable under the CFR given the lack of unified culture and legal language in the present day. ${ }^{55}$

The problem with harmonization of legal standards as proposed by the CFR is not only in the incoherence of the terminology across languages, but, more basically, the "lack of uniform concepts at EU level," particularly in consumer law. This also highlights the issue that no purely "European" culture, identity, or brand of thinking, ${ }^{57}$ exists that would assist the creation of a likewise common legal language; rather, "EU law ... is very much dependent on the terms and

49. Susan Šarčević, Creating a Pan-European Legal Language, in 117 LEGAL Discourse aCross LANGUAGes AND CULTURES 23, 23 (Maurizio Gotti \& Christopher Williams eds., 2010) (discussing the effect of plurilingual policy on national legal language and coherence and relativity of concepts).

50. Eur. Comm'n, European Contract Law-Common Frame of Reference, EUR. COMM'N, http://ec.europa.eu/consumers/rights/contract_law_en.htm (last updated Feb. 16, 2009); see Šarčević, supra note 49.

51. EUROPEAN UNION COMMITTEe, TWELFTH REPORT EUROPEAN CONTRACT LAW: THE Draft Common Frame of Reference, 2008-9, H.L. 12, ๆ 39, (U.K.), available at http://www.publications.parliament.uk/pa/ld200809/1dselect/1deucom/95/9507.htm

(discussing the purpose, history, and intentions of the Draft CFR as a "toolbox" for flexible interpretation and understanding).

52. E.g., Šrǎcević, supra note 49.

53. Id. at 24 (emphasis original) (referring to the common law of continental Europe formed by the reception of Roman law in the 17 th and 18 th centuries).

54. Id.

55. Id. at $24 \cdot 25$.

56. Id. at 26 .

57. See id. 
conceptual systems of the national legal systems of the Member States." 58 Germany's stance, when contrasted with other countries in the recent economic crises, particularly highlights the disconnect in thinking (though language was not the source of this particular problem). ${ }^{59}$ Even if the European Union could somehow create or decide on a common language, many legal academics "strongly believe that a common legal language in Europe cannot be a lingua franca such as English but must be a neutral meta-language ${ }^{60}$ with common legal concepts detached from their national laws, legal languages and cultures." ${ }^{61}$ Because language must link to underlying legal cultures, without a common European culture, the idea of a language detached from legal culture flies in the face of the very core ideas of legal language. However, some also suggest that creating an entirely new language would prove easier than "to synchronise the use of one language and its legal terminology in different national states." ${ }^{\prime \prime 2}$ In any case, the study of both law and language together as an interdisciplinary regimen remains crucial to further harmonization in either the realm of private law or legal language in general.

Another problem in the quest for coherence in EU directives is the lack of neutral terminology because of the differences in the civil and common law systems and individual national interpretations. ${ }^{63}$ Seemingly simple terms such as "good faith" lack common definitions and interpretations, and their translation only leads to more incoherence and confusion as the meaning in one language may be difficult to reconcile with another. ${ }^{64}$ Similarly, the problem of polysemy, common in legal language, also arises in this context when multiple words express the same concept in different places. ${ }^{65}$

As a remedy to some of these problems, the Draft CFR takes a new

58. Id. at 27.

59. See, e.g., Gavin Hewitt, Eurozone Crisis: The European Divide, BBC NEws (June 26, 2012) http://www.bbc.co.uk/news/world-europe-18591931 (discussing conflicting views about how to fix the EU economic crisis with Germany promoting austerity measures and France arguing for a bailout through bonds).

60. "[A] form of language or set of terms used for the description or analysis of another language." Definition of Metalanguage, OXFORDDICTIONARIES.COM, http://oxforddictionaries.com/definition/english/metalanguage (last visited Sept. 12, 2012).

61. Šarčević, supra note 49, at 26 (citing Marie-Jeanne Campana, Vers un langage juridique commun en Europe?, in LES MULTIPLES LANGUES DU DROIT EUROPÉEN UNIFORME (Rodolfo In Sacco \& Luca Castellani eds., 1999)).

62. Id. at 27 (quoting Viola Heutger, A More Coherent European Wide Legal Language, EUR. INTEGRATION ONLINE PAPERS (2004), available at http://eiop.or.at/eiop/texte/2004002a.htm).

63. See id. at $27-28$.

64. See id. at $29-30$.

65. See id. at 31. 
approach to language usage. ${ }^{66}$ The Draft CFR results from the collaborative work of numerous legal academics and serves as a starting point for the actual political version of the CFR. ${ }^{67}$ In it,"[a] conscious effort has been made to avoid technical terms of English law, making it clear that the terms are not to be defined in accordance with English legal concepts." ${ }^{68}$ The goal has been to relieve English of its common law baggage, making it equally palatable to those of both civil and common law backgrounds, but problems remain with this formula as well. ${ }^{69}$ Considerable resistance remains against the approach of the Draft CFR, however, because many common law lawyers fear that "Europe is aiming to civilise the common law." ${ }^{70}$ Many prefer to maintain their national law, language, and culture. Consequently, some have suggested that the CFR "serve as an 'optional instrument' representing an independent regime of contract law which the parties to a crossborder contract could opt into if they so choose" but this, too, has been met with significant criticism. The government of the United Kingdom even called that option "the Esperanto approach,""1 saying that "it would be uncomfortable and unfamiliar to everyone."72 As of now, discussion continues regarding the role of the Draft CFR in a larger political Common Frame of Reference. ${ }^{73}$

\section{Could There Be a Global Legal Language?}

In considering the current state of globalization, the importance and risks of the translation and interpretation of legal language, and the discussion about a pan-European language, it seems only natural to ask whether a global legal language or a true global lingua franca could exist. In actuality, such an idea appears to be nothing more than an

66. See id. at 34 .

67. Principles, Definitions and Model Rules of European Private Law: Draft Common Frame of Reference (DCFR), Outline Edition, at 3-6 (2009), available at http://ec.europa.eu/justice/policies/civil/docs/dcfr_outline_edition_en.pdf.

68. Šarčević, supra note 49 , at 34 .

69. See id. at 34-41.

70. Id. at 44 (quoting Lord Jonathon Mance, Is Europe Aiming to Civilise the Common Law?, 18 EUR. BUS. L. REV. 77 (2007)).

71. Paul Gershlick, Government Slams Proposed EU 28th Contract Law Regime as the Esperanto Approach, MATTHEW ARNOLD \& BALDWIN LLP (March 2, 2011), http://www.mablaw.com/2011/03/government-slams-proposed-eu-28th-contract-lawregime-as-the-esperanto-approach/.

72. Id.

73. See, e.g., Eur. Parliament Directorate-Gen. for Internal Pol'ys, Pol'y Dep't C: Citizens' Rts and Const. Aff., The Common Frame of Reference: An Optional Instrument? (2010) (by Evelyne Terryn), available at http://www.europarl.europa.eu/document /activities/cont/201004/20100430ATT73925/20100430ATT73925EN.pdf. 
extension of the ambitions of the European Union and the Draft CFR's metalanguage, and admittedly a similar concept has been tried in the form of neutral universal second languages, such as Esperanto, with relatively little success. ${ }^{74}$ In my opinion, given the current state of globalization's development, a global legal language presents more obstacles and disadvantages than advantages.

\section{A. Advantages and Obstacles to a Global Legal Language}

The advantages of a global legal language structure are relatively clear as they can be extrapolated from the smaller scale EU model. Use of a metalanguage or common language on a global scale would frequently reduce transaction costs of transnational dealings by creating a commonly understood legal structure and vocabulary and by reducing the necessity of translators and interpreters. ${ }^{75}$ It would promote globalization by encouraging transfer of goods and ideas and could theoretically advance the creation of a global culture to which the language could be linked. ${ }^{76}$ With a global language, parties to contracts would not always need choice of language clauses to protect themselves, and deciding between the English version and the Mandarin version of a contract would be a moot point.

However, some inherent obstacles to the adoption or creation of a neutral global language remain. If this were not the case, the translation and interpretation profession likely would not have survived nearly three millennia. ${ }^{77}$ Many of the problems noted in the example of the EU Draft CFR appear here as well: polysemy, redundancy, and lack of common concepts. However, the problems are magnified to a much larger scale when applied globally. The natural instability of language dominance provides one of the biggest hurdles to such a language: $:^{78}$

74. There are relatively few speakers of Esperanto in the world. As of 1998, there were only an estimated 2 million worldwide but more recent statistics are difficult to find. See An Update on Esperanto, UNIVERSALA EsPERANTO-Asocio (Sept. 2011), http://www.uea.org/info/angle/an_ghisdatigo.html (listing the number of "users" which have "some knowledge of Esperanto is in the hundreds of thousands and possibly millions.").

75. See, e.g., Šarčević, supra note 49 , at 25-26 (discussing the harmonization and convergence of law in the European context).

76. See id. at $25-26$ (discussing the facilitation of movement of ideas as a method of creating common language).

77. MATTILA, supra note 3 , at 7 (noting that the "long trail" of legal translation extends from as far back as $1271 \mathrm{BC}$ ); SIBIRSKY \& TAYLOR, supra note 7, at 9 (estimating the profession going back to third millennium BCE).

78. See MATTILA, supra note 3 , at 24 . 
One of the reasons for this fact is active States policy to gain international linguistic dominance: such dominance assures considerable power to dominant language countries. Through linguistic means, they can exercise great political, economic, and cultural influence in the international arena. At the same time, citizens of these countries enjoy a considerable advantage in various negotiations: the rhetoric of someone pleading in their mother tongue is always more convincing than rhetoric in a language of which one has less than full command. ${ }^{79}$

To have a global legal language, states must concede to the dominance of another language. This necessity conflicts with the rights of citizens to have access to legal systems in the language with which they are most comfortable, ${ }^{80}$ and also with general notions of state sovereignty inherent in international law. ${ }^{81}$ Moreover, the problem will still exist that every state will clearly prefer its own interpretation of even a common language over that of a rival simply due to the natural mutability of legal interpretation.

International law functions more or less because states willingly relinquish areas of their own sovereignty as long as other states will do the same. ${ }^{82}$ The problem with a global legal language, however, is that, unless an entirely new language is created, some states will suffer a disadvantage due to the unfamiliarity of the language chosen, while others will gain a distinct advantage because they will be using their mother tongue. Likewise, any new language will inevitably be the result of greater influence by some states than others. On the whole, it remains nearly impossible to create something neutral and unbiased. This issue can only be mitigated so far as the language can change to more of a neutral metalanguage that does not reflect a bias for the legal system and culture which bore it.

The potential for bias based on the associated legal system and culture of a language is inextricably linked to the inherent relativity of legal language on the whole. One essentially cannot fully understand the legal language outside the systemic context. This raises the issue of

79. Id.

80. See id. at 18 .

81. See, e.g., S.S. "Lotus" (France v. Turkey), 1927 P.C.I.J. (ser. A) No. 10, at 18-19 (Sept. 7) (holding that in the absence of a rule of international law, state sovereignty will rule).

82. Id. 
civil law and common law systems ${ }^{83}$ (not to mention other existing legal systems), ${ }^{84}$ as noted in passing, in the context of the European Union's CFR. The basic foundation for civil law and common law systems is so divergent in many respects that there often arise conceptual complications that are difficult to overcome. English-based systems, in particular, find their historical base in the common law. ${ }^{85}$ Conversely, much of the rest of the world adheres to a civil law system governed by a Civil Code, ${ }^{86}$ where no courts of equity exist and case law acts as a secondary consideration instead of a primary source of interpretation. Translation of certain terms into a new language can prove difficult even between civil law systems. ${ }^{87}$ Navigating the differences of the two conceptual systems of the law presents an enormous obstacle.

\section{B. English as a Candidate for Global Legal Language}

Within the modern context of language dominance, both Latin and French have enjoyed significant prestige throughout the course of history. However, as of late, the position of English in particular has strengthened rapidly worldwide, including among legal groups. ${ }^{88}$ Because English, but importantly not Anglification, ${ }^{89}$ was suggested as the vehicle for a pan-European metalanguage, I will examine the potential advantages and pitfalls of its use on a global scale.

The rapid growth and rise of English in recent years has made it by

83. Common and civil law both developed at roughly the same time in history, but common law comes from England, while civil law is essentially its continental counterpart. The main difference between the two is that common law is largely uncodified and is based almost solely on precedent set by the courts. Meanwhile, civil law is codified, and every possible cause of action is written down in a civil law system that is divided into categories of law and continuously updated. The judge plays very little role in the actual decision-making practices of justice in a civil law country. See The Common Law and Civil Law Traditions, RoBBins COLLECTION (2010), available at http://www.law.berkeley.edu/library/robbins/CommonLawCivilLawTraditions.html.

84. Religious law and customary law as well as mixed systems exist in many places in the world. See World Legal Systems, JURIGLOBE, http://www.juriglobe.ca/eng/index.php (last visited July 31, 2012).

85. MATTILA, supra note 3, at 221; Šarčević, supra note 49, at 34-40.

86. See MaTTILA, supra note 3, at 110; see also Šarčević, supra note 49 , at 34-40.

87. E.g., Martina Bajčić, Challenges of Translating EU Terminology, in 117 LEGAL Discourse aCROSS LANGUAGeS AND Cultures 75, 75 (Maurizio Gotti \& Christopher Williams eds., 2010) (noting the difficulties of translating EU concepts into Croatian, where many similar concepts did not previously exist).

88. MATTILA, supra note 3 , at 24.

89. Anglification, as used here, means a shift beyond just the language toward the English-style legal system. Šarčević, supra note 49 , at 25. 
far the best candidate for a global legal language. ${ }^{90}$ While more people speak Mandarin Chinese than any other language, English remains an official language in eighty-three countries and regions worldwide and is commonly regarded as the "most widely used 'second' and 'learning' language in the world." "91 Dominance, however, is very rarely accompanied by the neutrality necessary in such a broad linguistic role as global legal language. The economic and political power enjoyed by states that primarily speak English far outweighs that of any other nation or group. ${ }^{92}$ The hegemonic power of the United States and the public opinion of the country across the globe ${ }^{93}$ in particular endanger any potential neutrality that the second-language status of English could engender.

One major problem with the adoption of English as the global legal language comes from its relationship with the common law legal system. As mentioned above, the majority of legal systems follow civil law, ${ }^{94}$ and many of the concepts of common law, including those that go by the same or similar terms, have very different meanings in civil systems. The Central and Eastern European countries of the European Union provide an example of the difficulties of using English. The European Union writes directives in either French or English and then must translate them into each of the official national languages of the Member States. ${ }^{95}$ For many Member States, this presents little problem because they have worked so closely for many years, and, despite occasional divergence, learned users mutually understand many of the European continental concepts of law, such as the English respect for the judiciary. ${ }^{96}$ For others, like Eastern bloc countries, however, where

90. The Triumph of English: A world empire by other means, THE ECONOMIST, Dec. 20, 2001, available at http://www.economist.com/node/883997; see also MATTILA, supra note 3, at 24 (citing growing strength of English in the legal circles worldwide).

91. Most Widely Spoken Languages in the World, ONE WORLD Nations ONLINE, http://www.nationsonline.org/oneworld/most_spoken_languages.htm (last updated 2012).

92. See, The Triumph of English: A world empire by other means, supra note 90; see also, e.g., MATTILA, supra note 3 , at 25 (noting the tension between U.S. goals to limit translation into other languages and other languages' goals to strengthen their position).

93. See, Pakistani Public Opinion Ever More Critical of U.S., PEW REsEARCH CENTER (June 27, 2012), http://www.pewglobal.org/2012/06/27/pakistani-public-opinion-ever-morecritical-of-u-s/; see also Global Opinion of Obama Slips, International Policies Faulted, PEw RESEARCH CENTER (June 13, 2012), http://www.pewglobal.org/2012/06/13/globalopinion-of-obama-slips-international-policies-faulted/.

94. See World Legal Systems, supra note 84 (map showing civil law, common law, customary law, and religious law countries).

95. Šarčević, supra note 49, at 27; see MATTILA, supra note 3 , at 25.

96. See MATTILA, supra note 3 , at 107 (implying that while community law has continually developed, newcomers who are unfamiliar with the established system find themselves far behind the existing synergies of earlier-joining members). 
Roman law has had a less pronounced influence, ${ }^{97}$ and where language families are farther apart, translation can prove nearly impossible because of the complete absence of conceptual equivalencies. This particularly occurs where completely novel concepts introduced via European Community law must be incorporated into national legal systems. ${ }^{98}$ Meanwhile, new Member States in the European Union feel considerable pressure to meet linguistic and other benchmarks set by the European Commission. ${ }^{99}$ In any case, a global legal language would have to account for such gaps in concepts in a neutral manner.

Any suggestion to adopt English as a global legal language will likely face challenges based on the Western origins of the language and its accompanying culture. International law already appears very Western-centric. ${ }^{100}$ If English were somehow imposed on the global community as a global legal language, it would undoubtedly contribute to the Western conceptions of international law and would most likely do so at the expense of the unique features of other legal systems. This seems especially true in Asia and the Middle East, where the Western presence has not been felt as strongly as elsewhere. ${ }^{101}$ China in particular presents a unique example because its incredibly long dynastic history has combined with the Occidentalization of many areas of the law to create a truly unique legal system. ${ }^{102}$

The imposition of a global language would require a great amount of action by states who wish to participate; and, allowing reservations

97. Russia was relatively isolationist in its approach to legal linguistics for many years (until the fall of the USSR, essentially), even though the American and French approaches were more similar. Other smaller countries (like Croatia, formerly part of Yugoslavia) have such a brief history of their legal system they have trouble harmonizing. See Lelija Sočanac, Linguistic Transference in Croatian Law Articles, in 117 LEGAL DISCOURSE ACRoss LANGUAGES AND Cultures 109, 111 (Maurizio Gotti \& Christopher Williams eds., 2010). Legal linguistics overall has mainly been focused in the United States, France, and Russia. GALDLA, supra note 6, at 67.

98. See, e.g., Bajčić, supra note 87 , at 78 (considering the example of incorporation of the Posted Workers Directive into Croatian national law).

99. See id.

100. One example of the primarily Western origins of international law and its concepts is the definition of terms such as "terrorist" and "terrorism," which are highly subjective and ambiguous in nature. This is one example of the Western world's failure to account for differences in culture and understanding. Giorgia Riboni, Constructing the Terrorist in the Decisions of the Supreme Court of the United States and the European Court of Human Rights, in 117 LEgAL Discourse Across Languages AND Cultures 219, 219 (Maurizio Gotti \& Christopher Williams eds., 2010).

101. As compared to Africa and South America where long periods of European colonization drastically altered the existing native legal culture, many areas in Asia and the Middle East continue to be dominated by religious law, customary law, and a greater presence of mixed systems. See World Legal Systems, supra note 84.

102. Galdia, supra note 6 , at 70 . 
would risk destroying the entire regime. ${ }^{103}$ The most likely way to achieve such universal commitment would be to pass a Resolution in the General Assembly of the United Nations; however, even the United Nations does not include every state in the world, ${ }^{104}$ and some would inevitably suffer exclusion. ${ }^{105}$ In any case, most states would almost certainly resist relinquishing whatever power they may hold because of their ability to speak in their native tongue in exchange for an unproven global language that gives dominance to another language.

Overall, the hurdles for English, or any other existing language for that matter, likely remain far too great at present for a realistic opportunity to establish a global legal language. As with a pan-European language, it may only be a question of timing. ${ }^{106}$ While the need for a common conceptual ground is apparent in many contexts, and the desire exists at least on some level, the incentives must also exist to engage in the sacrifice of national language and culture that would likely accompany a convergence of law and the creation of a global culture. ${ }^{107}$ As the process of globalization continues, just as is currently happening within the European Union, "young lawyers [will be] taught common ... values, transnational legal concepts, and the multilingual terminology to express them." ${ }^{108}$ With such changes, it is possible that a global community will emerge and the conditions will be ripe for an equally global legal language. In any case, this clearly remains a slow progression, in which any rush or even adoption at an inopportune moment would likely lead to failure. In the meantime, other alternatives should be exploited to encourage the mutual understanding of national legal languages and cultures, which would prove necessary if the desire and need for a global legal language eventually ripen.

103. See generally U.N. Human Rights Comm., General Comment No. 24: Issues Relating to Reservations Made Upon Ratification or Accession to the Covenant or the Optional Protocols Thereto, or in Relation to Declarations Under Article 41 of the Covenant, CCPR/C/21/Rev.1/Add.6 (Nov. 4, 1994) (discussing interpretation of reservations for human rights treaties), available at http://www.unhchr.ch/tbs/doc.nsf/(Symbol)/69c55b086f72957ec12563ed004ecf7a?Opendocu ment.

104. See generally Member States of the United Nations, UNITED NATIONS, http://www.un.org/en/members/index.shtml (last visited Aug. 10, 2012).

105. Of the 196 recognized nations in the world, Kosovo, Taiwan, and Vatican City are not members of the United Nations; Vatican City and Palestine are recognized as Permanent Observers. Id.

106. Šarčević, supra note 49 , at $\mathbf{4 5 .}$

107. See id.

108. Id. 


\section{GROWING THE ROLE OF LAWYER-LINGUISTS AS A SOLUTION FOR LANGUAGE ISSUES ASSOCIATED WITH GLOBALIZATION}

While the path of globalization may eventually push us towards a truly global legal language whose unparalleled neutrality allows mutual understanding and usage to flourish in the global community without sacrificing too much of the value of the national languages and related cultures, such conditions remain very far removed from the present state. The international legal realm, in its current form, has rival languages battling for dominance ${ }^{109}$ and a reliance on professional, but fallible translation and interpretation specialists as liaisons for mutual understanding. ${ }^{110}$ The European Union, once again in the role of miniature model for globalization, has worked to reduce translation error and incoherence and to facilitate better mutual understanding by using a new kind of professional-the lawyer-linguist.

"Lawyer-linguists . . . are a relatively new type of profession[al] who came into existence following the creating of the EEC, EC, and EU and they typically work for the European institutions ... responsible for making legislation in a multiplicity of languages." 11 The goal of these professionals, trained in both language and the law, is essentially to close the gap between lawyers and linguists-translators that can create problems with the quality and equivalency of texts, ${ }^{112}$ by revising texts in their mother tongue and comparing the resulting text with a base text model. ${ }^{113}$ This method ensures greater accuracy and ensures a more faithfully equivalent translation.

Within the European Union, these lawyer-linguists work in teams of 4-5 per language, ${ }^{114}$ and affect nearly every aspect of European Union governance with their work. ${ }^{115}$ The unique thing about these professionals is that they understand the legal perspective in much more depth than traditional translators or interpreters. While

109. French and English are the most well-known of the language rivalries, but others exist and have throughout time, even back to the days of Latin dominance. MATTILA, supra note 3 , at 23-28, 258-59.

110. See SIBIRSKY \& TAYLOR, supra note 7, at 50 (describing interpreters as bridges in courtrooms and elsewhere).

111. Colin Roberston, Legal-linguistic Revision of EU Legislative Texts, in 117 LEGAL Discourse aCROSS Languages AND Cultures 51, 52 (Maurizio Gotti \& Christopher Williams eds., 2010).

112. Id.

113. Id. at 53.

114. Id. at 52 .

115. Id. at 52-53 (The European Central Bank, the European Court of Justice, the European Parliament, and the European Commission all utilize lawyer-linguists). 
translators have traditionally had very rigorous standards to adhere to, both ethically and qualitatively, the training offered and available remains a far cry from the training law schools provide students to "think like a lawyer" and to adequately interpret and shape texts and speech alike. ${ }^{116}$ Even court interpreters in the United States, though licensed, do not undergo any significant legal training. ${ }^{17} \mathrm{~A}$ common metaphor is that translators and interpreters act as the bridge between languages and cultures. ${ }^{118}$ Lawyer-linguists, however, have built a new and even stronger bridge by truly cultivating mutual understanding.

Lawyer-linguists typically possess the knowledge and depth of understanding necessary to reach the conceptual equivalent required in the translated legal document or message. The European Union recruits these professionals by holding competitions and having a very high bar for entry into employment. Mastery of a minimum of three languages, including the mother tongue, is required along with a law degree. ${ }^{119}$ Within the European Union, lawyer-linguists often engage in co-drafting. ${ }^{120}$ Co-drafting, or "codecision" within the context of the European Union, is a process that helps to assure that the maximum level of equivalency is achieved in legislative drafting. ${ }^{121}$ It allows for input and negotiations at multiple levels with teams of people. A legislative draft undergoes continual revision to achieve exactly the meaning desired by both the European Parliament and the European Council and is subject to "linguistic collaboration between the lawyer-linguists of the two institutions" at every stage to ultimately

\footnotetext{
116. There are very rigorous requirements for training, testing, and certification of interpreters across the world, particularly in the United States. There are a number of colleges that offer degree programs in translation and interpretation, and federal legislation requires that a court interpreter be certified. There are also programs available at the international level, and posts like those at the United Nations often require significantly more training than a standard translation or interpretation job. See SIBIRSKY \& TAYLOR, supra note 7, at 51-66 (introducing the training, testing, and certification in translation and interpretation provided in the United States and in other regions). Cf. Robertson, supra note 111 , at 53 (detailing the process and requirements for becoming a lawyer-linguist employed by the European Union; there is required participation in an open competition, and participants must have a law degree in addition to mastery of two foreign languages and their mother tongue).

117. See Court Interpreters Act, 28 U.S.C. $§ 1827$ (1996); see also ABA STANDARDS FOR LANGUAGE ACCESS IN COURTS, supra note 25.

118. SIBIRSKY \& TALOR, supra note 7, at 25.

119. Robertson, supra note 111 , at 53.

120. See Co-Decision or the "ordinary legislative procedure", EUROPEAN COMMISSION, http://ec.europa.eu/codecision/index_en.htm (last visited Sept. 8, 2012) (explaining the European Commission's procedure that is the equivalent of co-drafting); Robertson, supra note 111, at 60 (relating the details of the codecision procedure); ŚARČEVIĆ, supra note 38, at 181 (describing co-drafting as a creative process of translation employed in Canada).

121. See Co-Decision or the "Ordinary Legislative Procedure", supra note 120.
} 
achieve accuracy in each of the authentic European Union national languages. ${ }^{122}$

The European Union should not be the only organization in the international arena to take advantage of the benefits of these specialized professionals. The role of lawyer-linguists should greatly expand in both private and public international and transnational law.

In the private sector of law, lawyer-linguists appear to have gained at least a modicum of traction. Companies comprised of lawyer-linguists spring up to work for corporations that need their services in the many international business transactions completed every day. ${ }^{123}$ When companies engage in transactions in foreign jurisdictions, it remains standard to engage foreign counsel. ${ }^{124}$ The foreign counsel presumably has knowledge of both the laws and the standard customs observed by similarly situated corporations in that particular jurisdiction. ${ }^{125}$ While foreign counsel can often resolve many issues, other issues may arise, particularly in the context of negotiations, ${ }^{126}$ which are just as likely to be issues of understanding based on differing conceptual frameworks as issues of compliance with local law. In the case of issues based on conceptual and language differences, a lawyer-linguist would clearly possess the desired expertise, just as a tax lawyer would be consulted for questions of tax..$^{127}$ Such linguistic experts as lawyer-linguists would prove especially helpful in the drafting of international agreements affecting private law, such as bilateral investment treaties and regional agreements. $^{128}$

122. Robertson, supra note 111 , at 59-61.

123. There are firms comprised of "lawyer-linguists" with the goal of aiding private companies in the negotiation and understanding of their foreign business relations. E.g., TRANSLEGAL, http:/www.translegal.com (last visited Oct. 6, 2012); LAW LINGUISTS, http://www.lawlinguists.com (last visited Oct. 6, 2012).

124. It is a standard ethical requirement that an attorney must be licensed in the jurisdiction in which he or she practices. See, e.g., IND. ADMISSION AND DISCIPLINE R. 1 (2012).

125. See Working with Foreign Counsel: Pitfalls and Successes, ABA (May 20, 2011), http://www.abanow.org/2011/05/working-with-foreign-counsel-pitfalls-and-successes/ (discussing the expectations when working with foreign counsel).

126. Robertson, supra note 111 , at 61 .

127. See MoDel Rules PROF'L CoNDuCT R 1.1 (2012) ("A lawyer shall provide competent representation to a client. Competent representation requires the legal knowledge, skill, thoroughness and preparation reasonably necessary for the representation.").

128. "Agreement between two countries to ensure, among other things, that (1) investors of either country are allowed to hire top management personnel of any nationality, (2) have the right to make investment related transfers, (3) assets belonging to one country's investors in the other country can only be expropriated in accordance with the international law, and (4) investors will have access to binding international arbitration in dispute settlement." Bilateral Investment Treaty Definition, 
The public sector of international law is very different from the private sector where multinational corporations ${ }^{129}$ are the primary actors. In the public sphere, the primary actors are states themselves, but a number of important international organizations also exist. The United Nations ${ }^{130}$ obviously remains the most notable, but it is certainly not the only one. The World Trade Organization, International Monetary Fund, and various international lobbying groups and non-governmental organizations ${ }^{131}$ could also benefit from the use of lawyer-linguists. The United Nations is one of the most well-known users of translators and interpreters in the legal world. ${ }^{132}$ Particularly concerning definitions and concepts associated with human rights, opinions and understanding vary significantly from continent to continent and even among seemingly similar countries. Consider, for example, the definition of a terrorist. It could vary drastically depending on the region. Opinions in the United States differ markedly from those in the Middle East and parts of Asia. ${ }^{133}$ Lawyer-linguists could help to close this gap and to achieve mutual understanding that could facilitate a stronger international legal regime in the future.

With the increasing role of these new professionals, there are a few potential problems and consequences. The niche profession of lawyer-linguist seems most appropriate for translations of legal documents because of the depth and intricacies of legal language in written form. This may reduce the role of traditional legal translators to some extent, but interpretation will still remain a vital part of the legal world. The greatest potential barrier to the widespread use of

BUSINESSDICTIONARY.COM, available at http://www.businessdictionary.com/ definition/bilateral-investment-treaty.html (last visited Sept. 6, 2012).

129. "An enterprise operating in several countries, but managed from one (home) country. Generally, any company or group that derives a quarter of its revenue from operations outside its home country is considered a multinational corporation." Multinational Corporation (MNC) Definition, BUSINEsSDICTIONARY.COM, available at http://www.businessdictionary.com/definition/multinational-corporation-MNC.html (last visited Sept. 6, 2012).

130. See generally UnITEd NaTions, http://www.un.org/en (last visited Sept. 8, 2012).

131. See World Trade Organization, http://www.wto.org (last visited Sept. 8, 2012); see also INTERNATIONAL MONETARY FUND, http://www.imf.org (last visited Sept. 8, 2012); International Lobbying Bodies: EU/US, OXFORD UNIVERSITY PRESS, http://www.oup.com/uk/orc/bin/9780199533916/01student/exmaterial/page_33.htm (last visited Sept. 8, 2012) (listing various lobbying bodies); UN-NGO Relations, UN NONGOVERNMENTAL LIAISON SERVICE, http://www.un-ngls.org/orf/ngorelations.htm (last visited Sept. 8, 2012) (listing and describing what various non-governmental organizations do when working with the United Nations).

132. SIBIRSKY \& TAYLOR, supra note 7 , at 76 .

133. See Riboni, supra note 100, at 219 (discussing the different meanings of the terms "terrorism" and "terrorist" in the United States and in Europe). 
lawyer-linguists in both private and public international law remains the same as for a global legal language-acceptance by the relevant actors. It proves much easier, however, to make a case for lawyer-linguists, as their role will only help to further interaction among parties.

Overall, it is imperative that all parties reach a mutual understanding in whatever kind of agreement or transaction they carry out, whether spoken or written. ${ }^{134}$ Unfortunately, most current legal curriculum (particularly in the United States) only teaches the importance of understanding and using language appropriately in the context of a native language and teaches very little about international and cross-cultural communication and deeper topics on language and law. ${ }^{135}$ As we continue down the path of globalization, the next task for our law schools will be to prepare young attorneys for increasingly more encounters with those from different languages and cultural backgrounds. Scholars and practitioners from the international field recommend eliminating ambiguity as a method of reducing disputes. ${ }^{136}$ Regardless of the language or languages involved, mutual understanding and dispute reduction are worthwhile goals to pursue and, in the legal context, lawyer-linguists appear most adequately prepared to pursue them.

\section{CONCLUSION}

As our world continues down the path of globalization, the increased international interaction leads to greater potential for linguistic confusion and misunderstanding. Such issues prove especially perilous in a realm of language that requires such precision while simultaneously being fraught with redundancy and polysemy. English as a global legal language remains a poor and unrealistic solution to the problem. Many areas of the world seem unlikely to accept English over their own national languages (i.e., China). There are simply too many potential problems with imposing a Western language and its associated legal framework on the entire world. It also presents a chicken-before-the-egg kind of problem: A community must exist for a people to share a language, but likewise a shared language must exist

134. ARTHUR L. CORBIN, CoRBIN ON CONTRACTS 152-154 (West 1952) (discussing the risk of mistake as to words or meaning and the importance of a "meeting of the minds" in contracts).

135. See Husinec, supra note 33 , at 155,171 (recommending methods for teaching the intricacies of legal language for cross-cultural communication).

136. See Teachings of a Legal Linguist, BAKER \& MCKENZIE, www.bakermckenzie.com/FCTeachingsLegalLinguist/ (last visited Sept. 8, 2012). 
for the bonds of a community to form. Approaching the use of a global legal language and the formation of a global community must occur practically simultaneously but, as of yet, these steps remain slow.

The best solution at present is to continue to facilitate mutual understanding of legal systems and cultures, and to work toward the best equivalency in meaning by increasing the role of lawyer-linguists and encouraging more co-drafting in both public and private international law. The European Union has taken steps to grow the profession by employing its talents to reach equivalency in legislative directives, and such methods are also more commonly being used by private corporations and individual countries in treaty making and other forms of public law. To most effectively execute this type of change, however, legal education across the world must adapt to be more reflective of the issue and prepare future lawyers in the global world by not only teaching them how to think like lawyers in their own language, but in other languages as well. 
